\title{
PROBLEMATIKA PEMILIHAN KEPALA DAERAH SECARA LANGSUNG (DALAM PERSPEKTIF SOSIOLOGIS)
}

\author{
H. Djauhari \\ Fakultas Hukum Universitas Islam Sultan Agung (Unissula) Semarang
}

\begin{abstract}
Regional Head in a direct election indicates not yielded Regional Head of an ideal, in this case is suspected that some Regional Head who stumble legal cases of corruption. Such things can happen because of the democratic process in elections beginning with the starting pull of interest between the prospective head region with political parties on the one hand, and between candidates for the head area with his constituents on the other side. The implications of these conditions cause the cost of direct elections is quite expensive. With the number of political parties is quite large and there is no consciousness of the voters make choices based on conscience cannot be avoided in the elections always bring money politics (politics of money) / political horse-trading, and will bring leaders think moral hazard. These conditions are still just always happens in local elections democratic party directly. Such a case will be examined from a sociological aspect to bring up three issues, namely: the proliferation of political parties, money politics (money politics) / political horse-trading and the nature of moral hazard.
\end{abstract}

Keywords: direct election problems, sociological perspectives

\begin{abstract}
Abstrak
Pilkada langsung mengindikasikan belum memberikan hasil Kepala Daerah yang ideal, dalam hal ini ditengarai adanya beberapa Kepala Daerah yang tersandung kasus hukum korupsi. Hal yang demikian dapat terjadi karena proses demokrasi dalam pilkada diawali dengan tolak tarik kepentingan antara calon kepala daerah dengan partai politik pengusungnya pada satu sisi, dan antara calon kepala daerah dengan para pemilihnya pada sisi yang lain. Implikasi dari kondisi demikian menyebabkan biaya pilkada secara langsung cukup mahal. Dengan jumlah partai politik yang cukup besar dan belum adanya kesadaran para pemilih menentukan pilihan berdasar hati nurani tidak dapat dihindari dalam pilkada selalu memunculkan money politics (politik uang)/politik dagang sapi, kemudian akan memunculkan pemimpin berpikir aji mumpung. Kondisi demikian masih saja selalu terjadi dalam pesta demokrasi pemilihan kepala daerah secara langsung. Hal yang demikian akan ditelaah dari aspek sosiologis dengan memunculkan tiga permasalahan, yaitu: proliferasi partai politik, money poitics (politik uang)/politik dagang sapi dan sifat aji mumpung.
\end{abstract}

Kata kunci: problematika pilkada, secara langsung, perspektif sosiologis

Pendahuluan

Ketika reformasi bergulir tahun 1998, politik hukum otonomi daerah, yang di masa Orde Baru tertuang didalam UU Nomor 5 Tahun 1974, kembali dipersoalkan karena dianggap sebagai instrumen otoriterisme pemerintah pusat. UU Nomor 5 Tahun 1974 kemudian diganti dengan UU Nomor 22 Tahun 1999 yang kembali meletakkan prinsip otonomi luas dalam hubungan antara Pusat dan Daerah. Gagasan tersebut di mulai dengan memunculkan wacana federalisme yang kemudian ditolak banyak kalangan.
Gagasan federalisme ditentang keras oleh banyak kalangan, karena selain bertendensi membuang warisan berharga dan pesan sejarah yang sangat luhur dari para pendiri negara yang sangat arif, juga dianggap bertentangan dengan ketentuan dalam Pembukaan UUD 1945 (sila ketiga Pancasila) sebagai menganut bentuk negara kesatuan. Padahal, yang tercantum di dalam Pembukaan UUD 1945 adalah istilah persatuan bukan kesatuan. Sila ketiga Pancasila misalnya menyebut "Persatuan Indonesia". Sebenarnya, persatuan bangsa dapat terjadi baik di dalam negara kesatuan maupun di dalam 
negara federal. Di Amerika Serikat, Jerman, dan Malaysia, misalnya, terjadi persatuan yang sangat kokoh meskipun mereka berbentuk negara federal. Sebaliknya, di Inggris dan Indonesia selalu dihantui separatisme, meskipun betuk negaranya adalah kesatuan. Hal lain lagi adalah apa yang dialami oleh Uni Soviet dan Yugoslovakia yang hancur berantakan setelah selama bertahun-tahun mereka hidup dalam bentuk federal.

Baik bentuk negara kesatuan maupun bentuk negara federal tidak terkait langsung dengan kuat atau lemahnya "persatuan" suatu bangsa. Istilah persatuan dan kesatuan itu masing-masing memang mempunyai makna yang berbeda. Persatuan merujuk pada "psikopolitik" ketika rakyat ingin bersatu dalam satu ikatan kebangsaan, sementara itu kesatuan merujuk pada "struktur politik" yang dipilih di dalam UUD sebagai bentuk negara. Persatuan yang kokoh dapat tumbuh dan berkembang baik di dalam negara kesatuan maupun di dalam negara federal, sebaliknya perpecahan dapat muncul di dalam kedua bentuk negara tersebut.

Perdebatan yang menyangkut persoalan persatuan dan kesatuan itu akhirnya mengantar pada kesepakatan politik untuk tetap memilih sistem negara kesatuan dengan otonomi luas, tetapi dengan pembagian urusan antara Pusat dan Daerah menurut cara federalisme yang hanya menyerahkan hal-hal terbatas tertentu untuk diurus oleh Pusat. Dari perdebatan itulah akhirnya lahir UU tentang Pemerintah Daerah di era reformasi, yakni UU Nomor 22 Tahun 1999.

\section{Pembahasan}

Pemilihan Kepala Daerah dalam UU Nomor 22 Tahun 1999

Keluarnya UU Nomor 22 Tahun 1999, pengisian jabatan Kepala Daerah dan Wakil Kepala Daerah dilakukan oleh DPRD melalui pemilihan secara bersamaan. Calon Kepala Daerah dan calon Wakil Kepala Daerah ditetapkan oleh DPRD melalui tahap pencalonan dan pemilihan. ${ }^{1}$ Untuk pencalonan dan pemilihan Kepala

lemas Masithoh M. Noor, "Dinamika Pelaksanaan Fungsi legislasi DPRD Provinsi Dalam Penyelenggaraan Peme-
Daerah dan Wakil Kepala Daerah, dibentuk Panitia Pemilihan. Ketua dan para Wakil Ketua DPRD karena jabatannya adalah Ketua dan Wakil Ketua panitia Pemilihan merangkap sebagai anggota. Sekretaris DPRD karena jabatannya adalah Sekretaris Panitia Pemilihan, tetapi bukan anggota.

Panitia pemilihan bertugas melakukan pemeriksaan berkas identitas mengenai bakal calon berdasarkan persyaratan yang telah ditetapkan, melakukan kegiatan teknis pemilihan calon dan menjadi penanggungjawab penyelenggaraan pemilihan. Bakal calon Kepala Daerah dan bakal calon Wakil Kepala Daerah yang memenuhi persyaratan sesuai dengan hasil pemeriksaan yang dilakukan oleh Panitia Pemilihan, diajukan kepada DPRD untuk ditetapkan sebagai calon Kepala Daerah dan Wakil Kepala Daerah. Setiap fraksi melakukan kegiatan penyaringan pasangan bakal calon sesuai dengan syarat yang ditetapkan. Setiap fraksi menetapkan bakal calon Kepala Daerah dan Wakil Kepala Daerah dan menyampaikannya dalam rapat paripurna kepada pimpinan DPRD. Dua fraksi atau lebih dapat secara bersama-sama mengajukan pasangan bakal calon Kepala Daerah dan bakal calon Wakil Kepala Daerah.

Pemilihan Kepala Daerah dan Wakil Kepala Daerah dilaksanakan secara langsung, bebas, rahasia, jujur dan adil. Setiap anggota DPRD dapat memberikan suaranya kepada satu pasang calon Kepala Daerah dan calon Wakil Kepala Daerah dari pasangan calon yang telah ditetapkan oleh pimpinan DPRD. Pasangan caIon Kepala Darah dan calon Wakil Kepala Daerah yang memperoleh suara terbanyak pada pemilihan, ditetapkan sebagai Kepala Daerah dan Wakil Kepala Daerah oleh DPRD dan disahkan oleh Presiden. Kepala Daerah mempunyai masa jabatan lima tahun dan dapat dipilih kembali hanya untuk sekali masa jabatan. Kepala Daerah dilantik oleh Presiden atau pejabat lain yang ditunjuk untuk bertindak atas nama Presiden. Sebelum memangku jabatan-nya, Kepala Daerah mengucapkan sumpah/janji.

rintahan Daerah", Jurnal Litigasi Vol. 10 No. 1 Tahun 2009, Universitas Pasundan Bandung, hlm. 104 
Pelaksanaan demokrasi pilkada berdasarkan UU Nomor 22 Tahun 1999 ternyata masih dirasa kurang memuaskan oleh karenanya perlu diadakan perubahan lagi, kemudian lahirlah UU Nomor 32 Tahun 2004. ${ }^{2}$ Ketika UU Nomor 22 Tahun 1999 dilaksanakan, perkembangan di lapangan ternyata menimbulkan berbagai masalah yang tidak diduga sebelumnya, seperti semakin maraknya KKN.

Sejak lahirya UU Nomor 22 Tahun 1999, posisi DPRD menjadi sangat kuat. Lembaga ini bukan lagi menjadi bagian dari pemerintah daerah melainkan menjadi lembaga legislatif daerah yang sejajar dengan (dan dapat meminta, menerima, menolak dan menjatuhkan mosi kepada) Kepala Daerah. Anggota-anggota DPRD tidak dapat direcall, kewenangannya sangat besar dan kuat karena lembaga inilah yang memilih secara final kepala daerah untuk kemudian mengawasi, meminta laporan pertanggung jawaban, bahkan dapat menjatuhkannya. $^{3}$

Perubahan yang begitu signifikan dari sistem lama itu ternyata kemudian menimbulkan masalah besar. KKN di daerah bukan semakin hilang melainkan semakin subur di bawah sistem baru itu. Dalam setiap pemilihan kepala daerah selalu muncul politik uang dalam bentuk pembelian suara anggota-anggota DPRD. Ada juga pemerasan terhadap kepala daerah dengan menjadikan laporan pertanggung jawaban tahunan sebagai alatnya DPRD dalam penanganan proyek-proyek. ${ }^{4}$

Menghadapi persoalan-persoalan seperti itu, muncul kemudian gagasan untuk mengubah UU Nomor 22 Tahun 1999, guna disesuaikan dengan perubahan UUD 1945 sekaligus menutup celah-celah KKN. Tetapi perubahan itu dilakukan, dengan tidak mengganti paradigma dan visi yang dianut oleh UU Nomor 22 Tahun 1999. Salah satu hal yang paling menarik dan penting dari perubahan yang tertuang dalam UU Nomor

2 Amir F Kotarumalos, "Pemilihan Kepala Daerah Langsung; Suatu Upaya Membangun Demokrasi Diranah Lokal”, Jurnal Hipotesa Vol. 3 No. 1 Mei 2008, STIA Alaz$\mathrm{ka}, \mathrm{h} \mathrm{lm} .61$

3 Moh. Mahfud MD, 2006, Membangun Politik Hukum, Menegakkan Konstitusi, Pustaka LP3ES Indonesia, Jakarta, hlm. 229.

4 Ibid., hlm. 230.
32 Tahun 2004 adalah menyangkut pemilihan kepala daerah (pilkada) secara langsung. Pilkada langsung ini, selain ia bersifat demokratis sesuai dengan amanat konstitusi, sekaligus dimaksudkan juga untuk mengatasi politik dalam pemilihan kepala daerah melalui 'agen' atau 'calo', yakni DPRD. ${ }^{5}$

Selain tentang cara pemilihan kepala daerah, masalah hubungan hierarkis antara Provinsi dan Kabupaten/Kota serta tendensinya yang menimbulkan konflik antar daerah juga menjadi alasan yang cukup kuat untuk mengubah UU Nomor 22 Tahun 1999. Sejalan dengan itu, Sidang Tahunan MPR Tahun 2000 juga telah melakukan amandemen atas Pasal 18 UUD 1945 melalui amandemen kedua yang ternyata menghendaki pengaturan tentang pemerintahan daerah secara berbeda dari yang diatur di dalam UU Nomor 22 Tahun 1999.

Bunyi asli (sebelum amandemen kedua) Pasal 18 UUD 1945 adalah: Pembagian daerah Indonesia atau daerah besar dan kecil, dengan bentuk susunan pemerintahannya ditetapkan dengan undang-undang, dengan memandang dan mengingati dasar per-musyawaratan dalam sistem pemerintahan negara, dan hak-hak asal usul dalam daerah-daerah yang bersifat istimewa.

Penjelasan Pasal 18 UUD 1945 menyebutkan bahwa pertama, oleh karena Negara Indonesia utu suatu eenheidsstaat, maka Indonesia tak akan mempunyai daerah di dalam lingkungannya yang bersifat staat juga. Daerah Indonesia akan dibagi dalam daerah provinsi dan daerah provinsi akan dibagi pula dalam daerah yang lebih kecil. Di daerah-daerah yang bersifat otonom (streek dan locale rechtsge-menschappen) atau bersifat daerah administrasi belaka, semuanya menurut aturan yang akan ditetapkan dengan undang-undang. Di daerah-daerah

\footnotetext{
Bandingkan dengan Ni'matul Huda, "Pemilihan Kepala Daerah Secara Langsung Dalam Perspektif Yuridis", Jurnal Hukum Respublica Vol. 4 No. 2 Tahun 2005, Universitas Lancang Kuning Pekanbaru, hlm. 131-157; Sulardi, "Penyelengaraan Pemilihan Kepala Daerah Secara Langsung Oleh Rakyat; Sebuah Upaya Mengurangi Money Politic, Penguatan Kedaulatan Rakyat, Dan Menggeser Arah Pertanggungjawaban Kepala Daerah", Jurnal Legality Vol. 12 No. 12 Tahun 2004, FH UMM, hlm. 179-192.
} 
yang bersifat otonomi akan diadakan badan perwakilan daerah, oleh karena di daerah pun pemerintahan akan bersendi atas dasar permusyawaratan. Kedua, dalam teritori negara Indonesia terdapat lebih kurang 250 zelfbesturende landchappen dan volksgemenschappen, seperti di Jawa dan Bali, negeri Minangkabau, dusun dan marga di Palembang dan sebagainya. Daearah-daerah itu mempunyai susunan asli, dan oleh karenanya dapat diangap sebagai daerah yang bersifat istimewa. Negara Republik Indonesia menghormati kedudukan daerahdaerah istimewa tersebut dan segala peraturan Negara yang mengenai daerah-daeah itu akan mengingati hak-hak asal-usul daerah ter-sebut.

Adapun isi hasil Amandemen Kedua UUD 1945 dituangkan di dalam Pasal 18, 18A, dan $18 \mathrm{~B}$ yang selengkapnya menentukan:

(1) Negara Kesatuan Republik Indonesia dibagi atas daerah-daerah provinsi dan daerah provinsi itu dibagi atas kabupaten dan kota, yang tiap-tiap provinsi, kabupaten, dan kota itu mempunyai pemerintahan daeah, yang diatur dengan undang-undang.

(2) Pemerintahan daerah provinsi, daerah kabupaten, dan kota me-ngatur dan mengurus sendiri urusan pemerintahan menurus asas otonomi dan tugas pembantuan.

(3) Pemerintahan daerah provinsi, daerah kabupaten, dan kota memiliki Dewan Perwakilan Rakyat Daerah yang anggota-anggotanya dipilih melalui pemilihan umum.

(4) Gubernur, Bupati, dan Walikota masing-masing sebagai kepala pemerintahan daerah provinsi, kabupaten, dan kota dipilih secara demokratis.

(5) Pemerintahan daerah menjalankan otonomi seluas-luasnya, kecuali urusan peerintahan yang oleh undangundang ditentukan sebagai urusan Pemerintah Pusat.

(6) Pemerintahan daerah berhak menetapkan peraturan daeah dan peraturan-peraturan lain untuk melaksanakan otonomi dan tugas pembantuan.

(7) Susunan dan tata cara penyelenggaraan pemerintahan daerah diatur dalam undang-undang.

Pasal 18A :
(1) Hubungan wewenang antara pemerintah pusuat dan pemerintahan daerah provinsi, kabupaten, dan kota, atau antara provinsi dan kabupaten dan kota, diatur dengan undang-undang dengan memperhatikan kekhususan dan keragaman daerah.

(2) Hubungan keuangan, pelayanan umum, pemanfaatan sumber daya alam dan sumber daya daerah diatur dan dilaksanakan secara adil dan selaras berdasarkan undang-undang.

Pasal 18B :

(1) Negara mengakui dan menghormati satuan-satuan pemerintahan daerah yang bersifat khusus atau bersifat istimewa yang diatur dengan undangundang.

(2) Negara mengakui kesatuan-kesatuan masyarakat hukum adat beserta hakhak tradisionalnya sepanjang masih hidup dan sesuai dengan perkembangan masyarakat dan prinsip Negara Kesatuan Republik Indoonesia, yang diatur dalam undang-undang.

Perubahan isi Pasal 18 UUD 1945 itu menghendaki pengaturan secara lain yang lebih ketat dari yang diatur oleh UU Nomor 22 Tahun 1999, yang kemudian beberapa isi perubahan yang kemudian dituangkan di dalam UU Nomor 32 Tahun 2004, meliputi prinsip otonomi, pembagian urusan, dan hubungan hierarkis; pemilihan kepala daerah; pertanggungjawaban kepala daerah; sistem pengawasan; keuangan daerah; kepegawaian daerah; dan pemberhentian kepala daerah.

\section{Pemilihan Kepala Daerah dalam UU Nomor 32 Tahun 2004}

Kepala Daerah dan Wakil Kepala Daerah dengan ditetapkannya UU Nomor 32 Tahun 2004 tentang Pemerintahan Daerah, mempunyai peran yang sangat strategis dalam rangka pengembangan kehidupan demokratis, keadilan, pemerataan, kesejahteraan masyarakat, memelihara hubungan yang serasi antara Pemerintah dan Daerah serta antar Daerah untuk menjaga keutuhan Negara Kesatuan Republik Indonesia. Oleh karena itu, diperlukan figur 
Kepala Daerah dan Wakil Kepala Darah yang mampu mengembangkan inovasi, berwawasan ke depan dan siap melakukan perubahan ke arah yang lebih baik. ${ }^{6}$

Sejalan dengan pengembangan sarana demokrasi kedaulatan rakyat dalam Negara Kesatuan Republk Indonesia yang mendasarkan Panasila dan UUD 1945 serta UU Nomor 32 Tahun 2004 tentang Pemerintah Daerah, Kepala Daerah dan Wakil Kepala Daerah dipilih secara langsung oleh Rakyat yang dlaksanakan secara demokratis berdasarkan asas langsung, umum, bebas, rahasia, jujur dan adil melalui pemungutan suara. ${ }^{7}$ Proses pemilihan Kepala Daerah dilaksanakan melalui beberapa tahapan dimulai dari masa persiapan dan tahap pelaksanaan meliputi: persiapan pemilihan, penyelengggaraan pemilihan, penetapan pemilih, pendaftaran dan penetapan pasangan calon, kampanye, pemungutan dan penghitungan suara, serta penetapan pasangan calon terpilih, pengesahan dan pelantikan.

Pemilihan Kepala Daerah dan Wakil Kepala Daerah berdasarkan UU Nomor 32 Tahun 2004, dipilih dalam satu pasangan calon yang dilaksanakan secara demokratis berdasarkan asas langsung, umum, bebas, rahasia, jujur, dan adil. Pasangan calon diajukan oleh partai politik atau gabungan partai politik, yang harus memenuhi persyaratan sebagaimana yang dimuat dalam Pasal 58 UU Nomor 32 Tahun 2004 menyebutkan bahwa calon Kepala Daerah dan Wakil Kepala Daerah adalah warga negara Republik Indonesia yang memenuhi syarat: a). bertakwa kepada Tuhan Yang Maha Esa; b). setia kepada Pancasila sebagai Dasar Negara, Undang-undang Dasar Negara Republik Indonesia Tahun 1945, dan kepada Negara Kesatuan Republik Indonesia serta Pemerintah; c). Berpendidikan sekurang-kurangnya sekolah lanjut-

Muhammad Zein Abdullah, "Strategi Komunikasi Politik Dan Penerapannya Pada Pemilihan Kepala Daerah Secara Langsung Di Indonesia; Menuju Pemilu Yang Berkualitas", Jurnal Observasi Vol. 6 No. 1 Tahun 2008, Balai Pengakajian dan Pengembangan Informasi Wilayah II Bandung, hlm. 101

Ikhsan Syahrani, "Pemilihan Kepala Daerah Dan Wakil Kepala Daerah Secara Demokratis Berdasarkan UndangUndang Nomor 32 Tahun 2004", Jurnal Hukum Respublica Vol. 4 (2) tahun 2005, Universitas Lancang Kuning Pekanbaru, hlm. 170 an tingkat atas dan/atau sederajat; d). Berusia sekurang-kurangnya 30 (tiga puluh) tahun; e). sehat jasmani dan rohani berdasarkan hasil pemeriksaan kesehatan menyeluruh dari dokter; f). Tidak pernah dijatuhi pidana penjara berdasarkan putusan pengadilan yang telah memperoleh kekuatan hukum tetap karena melakukan tindak pidana yang diancam dengan pidana penjara paling lambat 5 (lima) tahun atau lebih; g).tidak sedang dicabut hak pilihnya berdasarkan putusan pengadilan yang telah memperoleh kekuatan hukum tetap; h). mengenal daerahnya dan dikenal oleh masyarakat di daerahnya; i). menyerahkan daftar kekayaan pribadi dan bersedia untuk diumumkan; j). tidak sedang memiliki tanggungan hutang secara perseorangan dan/atau secara badan hukum yang menjadi tanggung jawabnya yang merugikan keuangan negara; k). tidak sedang dinyatakan pailit berdasarkan putusan pengadilan yang telah memperoleh kekuatan hukum tetap; l). tidak pernah melakukan perbuatan tercela; $\mathrm{m}$ ). memiliki Nomor Pokok Wajib Pajak (NPWP) atau bagi yang belum mempunyai NPWP wajib mempunyai bukti pembayaran pajak; n). menyerahkan daftar riwayat hidup lengkap yang memuat antara lain riwayat pendidikan dan pekerjaan serta keluarga kandung, suami atau istri; o). belum pernah menjabat sebagai kepala daerah atau wakil kepala daerah selam 2 (dua) kali masa jabatan dalam jabatan yang sama dan, p). tidak dalam status sebagai pejabat kepala daerah. Terkait dengan persyaratan sebagaimana tersebut di atas, Mahkamah Konstitusi telah melakukan pengujian sebagai penegasan terhadap ketentuan dalam Pasal $58 \mathrm{f}$, tentang Mantan Narapidana, dan Pasal 58 o.

Ketentuan Pasal $58 \mathrm{f}$ yang pada intinya calon harus memenuhi syarat berupa tidak pernah dijatuhi hukuman pidana penjara berdasarkan putusan pengadilan yang telah memperoleh kekuatan hukum yang tetap melakukan tindak pidana yang diancam hukuman penjara paling lama 5 (lima) tahun atau lebih. Pasal ini dapat ditafsirkan luas sekali termasuk kejahatan yang dilakukan dalam rumah tangga, atau suatu delik culpa tetapi ancaman hu- 
kumannya lima tahun atau lebih. Padahal yang bersangkutan hanya dihukum beberapa bulan. Mahkamah Konstitusi dalam Putusan Nomor 13/PUU-V/2007 berpendapat bahwa ketentuan a quo berlaku dengan mengecualikan tindak pidana yang timbul karena kealpaan ringan (culpa lewis), dan tidak menyangkut kejahatan politik. Dalam perkembangannya pengujian terhadap Pasal 58 f UU Nomor 32 Tahun 2004, Mahkamah Konstitusi mengabulkan pembatasan pasal tersebut dengan persyaratan antara lain yang bersangkutan telah lima tahun sejak selesai menjalani hukuman, terus terang, tidak mengu-lang ulang perbuatannya. Persyaratan ini memungkinkan seseorang bekas narapidana mencalonkan diri sebagai calon Kepala Daerah, selain mengem-balikan citra seseorang dari stigma seorang penjahat yang tidak dapat menjadi orang baik sekalipun telah menebus dosanya dengan menjalani hukuman di lembaga permasyarakatan.

Sementara itu mengenai Masa Jabatan Kepala Daerah, sebagaimana yang diatur dalam Pasal 58 huruf o yang menyatakan bahwa "belum pernah menjabat sebagai kepala daerah atau wakil kepala daerah selama 2 (dua) kali masa jabatan dalam jabatan yang sama", keputusan pengujian yang dilakukan oleh Mahkamah Konstitusi terkait dengan kasus Calon Bupati dalam Pemilihan Umum kepada daerah/ wakil kepala daerah Kabupaten Jembrana Tahun 2010. sebagaimana yang tertuang dalam Putusan Nomor 8/PUU-VI/2008, telah memberikan batasan Kepala Daerah. Pembatasan di maksud dapat diimplementasikan oleh Undangundang dalam bentuk : (i) pembatasan dua kali berturut-turut dalam jabatan yang sama, atau (ii) pembatasan dua kali yang berturut-turut, atau (iii) pembatasan dua kali dalam jabatan yang sama di tempat yang berbeda. Oleh karena itu pembatasan dimaksud terbuka bagi pembentuk Undang-undang sebagai pilihan kebijakan, maka hal demikian tidak bertentangan dengan UUD 1945. Penafsiran tersebut di atas belum menjawab persoalan apakah jika seorang Wakil Bupati di tengah masa jabatannya menggantikan Bupati, karena Bupati berhalangan tetap, sehingga kurang dari lima tahun diang- gap satu kali masa jabatan ataukah tidak, demikian juga apakah seorang Bupati yang diangkat dan ditetapkan sebagai Bupati berasaskan Undang-undang Nomor 22 Tahun 1999, kemudian di tengah masa jabatannya Undangundang Nomor 22 Tahun 1999 dicabut dengan Undang-undang Nomor 32 Tahun 2004, dianggap telah menjabat satu kali masa jabatan ataukah tidak.

Untuk menjawab hal tersebut Mahkamah Konstitusi nengembangkan penafsiran sehingga sekalipun terdapat perubahan Undang-undang (UU Nomor 22 Tahun 1999 dicabut dan diganti dengan UU Nomor 32 Tahun 2004 juncto PP Nomor 6 Tahun 2005) tetapi kedua Undang-undang tersebut menentukan batas masa jabatan sama yaitu lima tahun untuk satu kali masa jabatan, maka perhitungan satu kali masa jabatan tidak terhalang oleh adanya perubahan Undangundang. Jika terjadi penggantian jabatan karena Bupati berhalangan tetap maka penggantinya melanjutkan masa jabatan tersebut hingga habis masa jabatannya. Apakah sisa masa ja-batan itu dihitung satu kali masa jabatan ataukah tidak didasarkan atas asas proporsio-nalitas dan rasa keadilan. Mahkamah Konstitusi berpendapat bahwa separo masa jabatan atau lebih dihitung satu kali masa jabatan. Putusan Nomor 130-VI-PUU/2009 tanggal 17 Nopember 2009 intinya menyatakan jika seseorang telah menjabat Kepala Daerah atau sebagai pejabat Kepala Daerah separo atau lebih masa jabatan maka yang bersangkutan dihitung telah men-jabat satu kali masa jabatan. ${ }^{8}$

Partai politik atau gabungan partai politik mendaftarkan pasangan calon apabila memenuhi persyaratan perolehan sekurang-kurangnya 15\% (lima bekas persen) dari jumlah kursi DPRD atau 15\% (lima belas persen) dari akumulasi perolehan suara sah dalam Pemilihan Umum anggota DPRD di daerah yang bersangkutan. Partai politik atau gabungan partai politik wajib membuka kesempatan yang seluas-

8 Eddy Asnawi, "Tinjauan Hukum dan Politik Pemilihan Kepala Daerah menurut Undang-Undang Nomor 32 tahun 2004", Jurnal Hukum Respublica Vol. 4 (2) Tahun 2005, Universitas Lancang Kuning Pekanbaru, hlm.164165 
luasnya bagi bakal calon perseorangan yang memenuhi syarat dan selanjutnya memproses bakal calon dimaksud melalui mekanisme yang demokratis dan transparan. Dalam proses penetapan pa-sangan calon, partai politik atau gabungan partai politik memperhatikan pendapat dan tanggapan masyarakat.

Sebagaimana yang diatur dalam Pasal 59 ayat (2) menyebutkan: Partai politik atau gabungan partai politik sebagaimana dimaksud pada ayat (1) dapat mendaftarkan pasangan calon apabila memenuhi persyaratan perolehan sekurang-kurangnya 15\% (lima belas persen) dari akumulasi perolehan suara sah dalam Pemilihan Umum anggota DPRD di daerah yang bersangkutan.

Terkait ketentuan Pasal 59 ayat (2) di atas, pernah dimintakan judicial review ${ }^{9}$ oleh Ferr Tinggogoy dan kawan-kawan kepada Mahkamah Konstitusi, dan Mahkamah Konstitusi mengabulkan permohonan judicial review itu sehingga parpol-parpol yang tidak memiliki kursi di DPRD dapat mengajukan calon pasangan asalkan secara komulatif memiliki minimal $15 \%$ suara pemilih di daerah yang bersangkutan. Judicial review Mahka-mah Konstitusi atas UU Nomor 32 Tahun 2004 tidak mengubah ketentuan bahwa pencalonan Kepala Daerah/ Wakil Kepala Daeareah harus melalui parpol atasu gabungan lebih dari satu parpol. Mahkamah Konstitusi hanya mene-tapkan bahwa parpol yang tidak memperoleh kursi di DPRD boleh mencalonkan secara gabungan asalkan jumlah suara gabungan itu mencapai sejumlah suara pemilih tertentu $(15 \%) .{ }^{10}$

Mulai sejak tahun 2005 dengan bergulirnya waktu di era Reformasi hampir seluruh daerah di Nusantara telah melaksanakan pemilihan pimpinan daerah masing-masing dengan suasana demokratis sebagaimana yang dimanatkan Pasal 18 ayat (4) UUD NRI Tahun 1945, dan

\footnotetext{
9 Laica Marjuki menyamakan judicial review dengan constitutional review, yakni kewenangan pengujian yang diserahkan kepada lembaga peradilan seperti halnya dengan Supreme Court (USA) dan Constitutional Court.Lihat dalam Laica Marjiko, "Membangunan Undang Undang Yang Idial”, Jurnal Legislasi Indonesia Vol. 4 (2) tahun 2007, Departemen Hukum dan Ham Jakarta, hlm. 6

10 Moh. Mahfud MD, op.cit, hlm. 234.
}

Pasal 1 Undang-undang Nomor 22 Tahun 2009 tentang Penyelenggaraan Pemilihan Umum. Dari hasil pesta demokrasi yang menghasilkan Gubernur dan Wakil Gubernur dan Bupati/Wakil Bupati serta Walikota/Wakil Walikota ternyata derap langkahnya dalam membangun daerah masing-masing masih sering menampakkan ketidaksesuaian janji yang disampaikan saat kampanye, bahkan masih banyak kepala daerah yang tersandung kasus hukum karena tindakan pelaggaran hukum yang dilakukan. Di samping itu dalam pesta demokrasi dalam pelaksaan pilkada sering terjadi kasus sengketa mengenai perolehan hasil suara yang melibatkan para pendukung masing-masing calon, yang berujung pada pertikaian. Bahkan juga banyak dari Kepala Daerah yang terjerat kasus hukum. Menyikapi hal de-mikian, akhir-akhir ini muncul dari berbagai tokoh masyarakat, para pejabat pemerintah dan para tokoh politik melontarkan pemikiran pemilihan Gubernur tidak perlu dipilih langsung oleh rakyat tetapi cukup dipilih oleh DPR.

Fenomena di atas mengindikasikan bahwa tampilnya seorang Kepala Daerah apakah Gubernur/Wakil Gubernur, Bupati/Wakil Bupati, dan Walikota/Wakil Walikota yang telah memenuhi berbagai persyaratan sesuai aturan hukum yang berlaku, serta membutuhkan pengorbanan besar dari segi materiel dan nonmateriel, ternyata belum memberikan hasil sebagaimana yang diamanatkan reformasi. Dari sisi pelaksanaan Pilkada juga ada indikasi mayoritas pelak-sanaan pilkada menimbulkan sengketa yang berujung sengketa pilkada ke Mahkamah Kons-titusi. Sebagaimana informasi yang disampaikan oleh Sekretariat Mahkamah Konstitusi, bahwa selama tahun 2010 ini telah dilaksanakan se-banyak 244 pilkada. Dari pelaksanaan pilkada tersebut memunculkan sengketa pilkada yang masuk ke Mahkamah Konstitusi sebanyak 230 perkara, dengan rincian 215 perkara sudah di-putuskan, 6 dalam pemeriksaan dan 9 me-nunggu putusan. Dari proses perkara pilkada tersebut 23 perkara dikabulkan, 145 ditolak, dan 43 tidak dapat diterima. Dari seluruh pe-laksanaan pilkada hanya 58 pilkada $(25,55 \%)$ yang tidak ada 
sengketa di Mahkamah konstitusi. Bahkan juga banyak dari Kepala Daerah yang terjerat kasus hukum.

\section{Pemilihan Kepala Daerah Secara Langsung dari Perspektif Sosiologis}

Seseorang yang akan mencalonkan diri sebagai Kepala Daerah harus memenuhi persyaratan yang diatur dalam UU Nomor 32 Tahun 2004 tentang Pemerintahan Daerah. Sebagaimana yang termuat dalam Pasal 58 telah mengatur persyaratan yang harus dipenuhi oleh calon Kepala Daerah dan Wakil Kepala Daerah, yang secara rinci terdiri dari 16 poin sebagaimana yang tersebut di atas. Apabila dilihat dari syarat-syarat dalam Pasal 58 tersebut ternyata sudah menunjukkan begitu luas cakupannya meliputi segi loyalitas berbangsa dan bernegara, pendidikan, kekayaan dan seterusnya. Sementara itu, dalam Pasal 59 (5) mengatur persyaratan yang harus dipenuhi oleh partai politik atau gabungan partai politik pada saat mendaftar-kan pasangan wajib menyerahkan 6 (enam) macam pernyataan yang dibuat oleh calon Kepala Daerah.

Seyogianya dalam surat pernyataan yang dibuat oleh calon Kepala Daerah yang diserahkan kepada partai politik pengusung pada saat mendaftar perlu dibuat surat pernyataan bahwa calon Kepala Daerah tidak menjanjikan dan/atau memberikan atau materi lainnya un-tuk mempengaruhi pemilih. Walaupun hal ini memang sudah secara tegas diatur dalam Pasal 82.

Hal demikian dianggap penting dengan mendasarkan pemikiran dari Chambliss dan Seidman, bahwa suatu peraturan/hukum dapat berjalan efektif tidak hanya dilihat dari segi peraturan/hukum itu sendiri, namun masih ada faktor lain yang berpengaruh yaitu aparat penegaknya maupun masyarakat, dan faktorfaktor sosial dan personal. Dengan dibuatnya pernyataan oleh pasangan calon tersebut di harapkan sebagai upaya preventif sejak awal bagi pasangan calon dan bagi partai politik pengusung tidak akan melakukan politik uang. Terkait dengan faktor sosiologis dalam pelak- sanaan Pilkada yang masih jauh dari harapan dan terjadi banyak penyimpangan ini akan dianalisis dari aspek proliferasi partai politik, money politics (politik uang)/politik dagang sapi dan sifat aji mumpung.

\section{Proliferasi Partai Politik}

Tidak dapat dipungkiri munculnya partai politik bagaikan jamur di musim hujan, akan menjadikan masyarakat terkotak-kotak dalam mementukan pilihannya yang pada ujungujungnya akan terjadi tolak tarik bagi kepentingan politik. Banyaknya partai politik di Indonesia di awal reformasi mencapai jumlah yang mencapai sekitar 300 parpol dapat dibilang sebagai pemenang 'Guinness Book of Record' sebagai negara yang memiliki parpol paling banyak di dunia. ${ }^{11}$ Hal yang demikian juga mengindikasikan masyarakat kita terkotakkotak dalam sejumlah partai politik tersebut.

Pertumbuhan parpol yang luar biasa banyaknya setidaknya mengindikasikan Pertama, proliferasi parpol-parpol men-cerminkan perkembangan politik Indonesia masih tetap di dominasi euphoria kebebasan daripada pertimbangan dan rasionalitas terhadap realitas politik seperti dalam proses-proses politik yang berlangsung. Hal yang demikian dapat memunculkan masalah dan komplikasi baru yang kontra-produktif, jika tidak merugikan bagi aktualisasi demokrasi Indonesia. Parpol kecil/ gurem tidak melihat realitas politik yang cukup pahit bagi mereka untuk kemudian melakukan langkah-langkah yang lebih realistis dan viable secara politik. Kalaupun ada langkah yang mereka lakukan, maka itu hanyalah dalam bentuk aliansi dan koalisi yang sangat longgar dan kerenanya, sangat rentan terhadap konflik di antara para pemimpin parpol yang terlibat dalam persekutuan semacam ini.

Kedua, proliferasi parpol jelas hanya akan meningkatkan fragmentasi politik dan sosial, tidak hanya di kalangan elit politik, tetapi juga di kalangan masyarakat secara keselu-

\footnotetext{
11 Lihat Djauhari, “Proliferasi Partai Politik, Civil Society, dan Demokratisasi di Era Reformasi”, Jurnal Hukum Vol. XIV (2) Oktober 2004, FH Universitas Islam Sultan Agung Semarang, hlm.209
} 
ruhan. Parpol-parpol besar saja masih menyisakan konflik dan fragmentasi sosial-politik baik di kalangan kepemimpinan maupun di antara massa pendukung mereka. Apabila hal ini sampai pada tingkat massa, maka mungkin akan muncul fragmentasi yang teraktualisasi konflik terbuka yang dapat berubah menjadi kekerasan dan anarki, bahkan dapat dikhawatirkan akan meningkat bersamaan dengan peningkatan suhu politik. Apabila parpol memperlihatkan perangai yang mementingkan diri sendiri dan egoistis, maka akan melahirkan pertanyaan sangat serius mengenai kemampuan political society se-bagai lokomotif untuk membangun masa depan Indonesia yang lebih demokratis.

Indikator tersebut di atas dapat diduga akan menampilkan proses pemilihan Kepala Daerah dan diusung oleh parpol-parpol yang memenuhi persyaratan, akan menampilkan langgam proses pemilihan yang nampak di permukaan berjalan secara demokratis, namun kemungkinan akan terjadi tolak-tarik kepentingan parpol yang secara realitas memang jauh lebih banyak dari parpol yang mengusung calon Kepala Daerah. Hal yang demikian berakibat masyarakat akan terkotak-kotak mengikuti irama dari pimpinan parpol mereka. Dengan demikian mungkin tidak akan ada parpol pengusung pilkada yang memenangkan Kepala Daerah dengan mayoritas mutlak, dan tidak ada alternatif kecuali mengadakan koalisi dengan partai politik yang lain. Bagaimanapun juga, koalisi akan terwujud dengan baik kalau memenuhi dua syarat: pertama, partai yang berkoalisi memiliki kedekatan ideologis; kedua, partai yang berkoalisi memiliki kepentingan yang sama yang mendesak.

Namun, karena sistem multi partai yang diterapkan di masyarakat Indonesia yang sangat pluralistik dan terpisah dalam kutub-kutub yang berjauhan yang hampir tidak mungkin dikompromikan, dan sangat sulit dicapai karena partai-partai mewakili kepentingan yang sempit, seperti kedaera-han, keagamaan, dan bahkan klik-klik politik.

Partai politik dalam negara demokratis menyelenggarakan beberapa fungsi sebagai sarana komunikasi politik; sarana sosialisasi politik; sarana recruitment politik, dan sarana pengatur konflik conflict mana-gement). ${ }^{12}$ Dalam praktik politik sering dilihat bahwa fungsi-fungsi tersebut di atas tidak dilaksanakan seperti yang diharapkan. Misalnya informasi yang diberikan justru menimbulkan kegelisahan dan perpecahan dalam masyarakat, yang dikejar bukan kepentingan nasional, anak tetapi kepentingan partai yang sempit dengan ajibat pengkotakan politik, atau konflik tidak di selesaikan, akan tetapi malah dipertajam. ${ }^{13}$

Sementara itu tidak dapat dipungkiri bahwa keberadaan organisasi termasuk organisasi partai politik cenderung berifat oligarkis, kadang-kadang bertindak dengan lantang untuk dan atas nama kepentingan rakyat, tetapi justru berjuang untuk ke-pentingan pengurusnya sendiri. Seperti dikemukakan oleh Robert Michels sebagai suatu hukum besi yang berlaku dalam organisasi bahwa organisasilah yang me-lahirkan dominasi si terpilih atas para pemilihnya, antara si mandataris dengan di pemberi mandat dan antara si penerima kekuasaan dengan sang pemberi. Siapa saja yang berbicara tentang organisasi, maka sebenarnya ia berbicara tentang oligarki.

\section{Money Politics (Politik Uang)/Politik Dagang Sapi}

Masyarakat terkotak-kotak dengan banyaknya partai politik, kemungkinan dan hampir pasti calon pasangan atau melalui parpol pengusung dan tim kampanyenya akan berusaha keras untuk dapat mempengaruhi calon pemilih dengan suatu janji atau iming-iming tertentu. Dalam kondisi masyarakat yang masih dalam proses demokrasi dan persoalan ekonomi yang masih menghimpit kehidupan, cara mempengaruhi pemilih melalui pemberian uang adalah suatu hal yang sulit dihindari, karena dalam menentukan pilihan bukan berdasar 'hati nurani', tetapi lebih didasarkan pada nilai untung rugi dan lebih lagi untuk dapat menopang

\footnotetext{
12 Miriam Budiardjo, 2001, Dasar-Dasar Ilmu Politik, Jakarta:Gramedia Pustaka Utama, hlm. 164.

13 Loc.cit
} 
kebutuhan kehidupan. ${ }^{14}$ Tidak dapat kita pungkiri, praktik money politics (politik uang)/politik dagang sapi ini masih sulit untuk diberantas/diberhentikan, bahkan pada tingkat pemilihan kepala desa sekalipun tidak lepas dari cara yang demikian. Walaupun perbuatan yang demikian dengan tegas dilarang sebagaimana yang termuat dalam Pasal $82 \mathrm{UU}$. Nomor 32 Tahu 2004, yang menentukan:

(1) Pasangan calon dan/atau tim kampanye dilarang menjanjikan dan/atau memberikan uang atau materi lainnya untuk mem-pengaruhi pemilih.

(2) Pasangan calon dan/atau tim kampanye yang terbukti melakukan pelanggaran sebagaimana dimaksud pada ayat (1) berdasarkan putusan pengadilan yang telah mempunyai kekuatan tetap dikenai sanksi pembatalan sebagai pasangan calon oleh DPRD.

Ada dugaan baru atau setidak-tidaknya kemungkinan baru bergesernya cara money politics (politik uang)/politik dagang sapi dari 'eceran' pencalonan pada pemilihan Kepala Daerah/Wakil Kepala Daearah. Jika di masa berlakunya UU Nomor 22 Tahun 1999 calon Kepala Daerah dapat menjadi calon dengan membayar secara eceran kepada (oknumoknum) Fraksi di DPRD , karena pasangan calon harus dicalonkan oleh Fraksi, maka dengan berlakunya UU Nomor 32 Tahun 2004, money politics (politik uang)/politik dagang sapi dilakukan secara borongan dengan membeli rekomendasi pencalonan dari (oknum) pimpinan partai. Meski hal yang demikian sulit untuk dibuktikan, karena yang membayar dan yang menerima uang saling melindungi, hal yang demikian sering dimuat oleh media massa. Apabila money politics (politik uang)/politik dagang sapi masih saja terus terjadi, maka dapat kita bayangkan nanti saatnya duduk di kursi singgasana Kepala Daerah.

\section{Sifat Aji Mumpung}

14 Lihat Hamdan M, “Faktor Yang Mempengaruhi Terjadinya Money Politic Dalam Pemilihan Kepala Daerah Dan Cara Penanggulangannya”, Jurnal Ilmu Hukum Kanun Vol. 15 (41) Tahun 2005, Universitas Syiah Kuala Banda Aceh, hlm. 127-140
Dari proses pelaksanaan Pilkada yang telah menyita waktu, tenaga dan biaya yang cukup besar, namun masih juga belum mendapatkan Kepala Daerah yang ideal dan dapat menyejahterakan masyarakat, bahkan terkesan bersifat "aji mumpung". Hal yang demikian dapat terjadi dengan tampil sebagai Kepala Daerah dalam waktu masa jabatan terbatas selama lima tahun, sementara biaya yang dikeluarkan dalam proses pilkada cukup tinggi yang disinyalir berkisar antara 10 milyar untuk Bupati/Walikota dan 25 milyar untuk Gubernur, lalu muncul pertanyaan kapan uang saya dapat kembali.

Peringatan terhadap perilaku dengan mendasarkan sifat "aji mumpung" ternyata sesuai dengan pemikiran yang pernah dinyatakan oleh Lord Acton, bahwa kekuasaan itu cenderung korup/disalah gunakan, dan kekuasaan yang absolut cenderung korup/di-salah gunakan secara absolut: Power tends to corrupt, and power absolute tends to corrupt absolutely.

Baru-baru ini Menteri Dalam Negeri menyatakan bahwa saat ini semakin banyak kepala daerah yang telah ditetapkan menjadi tersangka kasus korupsi, sedikitnya terdapat 158 kepala daerah di tanah air yang menjadi tersangka korupsi. ${ }^{15}$

\section{Penutup}

Simpulan

Berdasarkan pembahasan di atas, maka terdapat beberapa yang dapat disimpulkan. Pertama, pemilihan Kepala Daerah Secara Langsung dimulai sejak 2005 dengan dikeluarkannya UU Nomor 32 Tahun 2004 sebagai pengganti UU Nomor 22 Tahun 1999, selain bersifat demokratis sesuai amanat konstitusi, sekaligus diharapkan untuk mengatasi politik pemilihan kepala daerah melalui agen atau calo. Namun dalam pelaksanaannya (selama 5 tahun) masih mengindikasikan pada tataran bentuk belum pada tataran hasil yang ideal.

Kedua, terkait dengan masa jabatan kepala daerah yang diatur dalam Pasal 58 huruf o

\footnotetext{
15 Suara Merdeka, 19 Pebruari 2011, hlm. 12.
} 
dan seseorang mantan nara pidana yang mencalon diri sebagai kepala daerah sebagaimana yang tertuang dalam Pasal 58 huruf $f$ UU Nomor 32 Tahun 2004 Mahkamah Konstitusi telah mengembangkan hukum lewat jurisprudensi ketatanegaraan.

Ketiga, terdapat indikasi kurangnya efektivitas hukum terkait dengan pesta demokrasi pelaksanaan pemilihan kepala daerah karena adanya pengaruh faktor sosiologis yang ditengarai dengan adanya proliferasi partai politik, money politics (politik uang)/politik dagang sapi dan aji mumpung.

\section{Saran}

Mencermati ketiga simpulan tersebut, maka terdapat beberapa saran penulis berupa Pertama, perlu diadakan persyaratan yang lebih tegas bagi calon Kepala Daerah agar tidak terkesan bahwa orang yang mampu (berduit) yang dapat lolos dalam pencalonan; kedua, penyadaran masyarakat untuk memilih dengan berdasar hati nurani.

\section{Daftar Pustaka}

Abdullah, Muhammad Zein. "Strategi Komunikasi Politik dan Penerapannya pada Pemilihan Kepala Daerah Secara Langsung Di Indonesia; Menuju Pemilu Yang Berkualitas". Jurnal Observasi Vol. 6 No. 1 Tahun 2008. Bandung: Balai Pengakajian dan Pengembangan Informasi Wilayah II;

Asnawi, Eddy. "Tinjauan Hukum dan Politik Pemilihan Kepala Daerah menurut UU No. 32 tahun 2004". Jurnal Hukum Respublica Vol. 4 No. 2 Tahun 2005. Pekanbaru: Universitas Lancang Kuning;

Budiardjo, Miriam. 2001. Dasar-Dasar Ilmu Politik. Jakarta: Gramedia Pustaka Utama;

Djauhari. "Proliferasi Partai Politik, Civil Society, dan Demokratisasi di Era Reformasi”.
Jurnal Hukum Vol. 14. No. 2 Oktober 2004. Semarang: FH Universitas Islam Sultan Agung;

Huda, Ni'matul. "Pemilihan Kepala Daerah Secara Langsung Dalam Perspektif Yuridis". Jurnal Hukum Respublica. Vol. 4 No. 2. Tahun 2005. Pekanbaru: Universitas Lancang Kuning;

Kotarumalos, Amir F. "Pemilihan Kepala Daerah Langsung Suatu Upaya Membangun Demokrasi Diranah Lokal". Jurnal Hipotesa. Vol. 3 No. 1 Mei 2008. Ambon: STIA Alazka;

M, Hamdan. "Faktor Yang Mempengaruhi Terjadinya Money Politic dalam Pemilihan Kepala Daerah dan Cara Penanggulangannya". Jurnal Ilmu Hukum Kanun Vol. 15 No. 41 Tahun 2005. Banda Aceh: Universitas Syiah Kuala;

Marjuki, Laica. "Membangunan Undang Undang Yang Idial". Jurnal Legislasi Indonesia Vol. 4 No. 2 tahun 2007. Jakarta: Departemen Hukum dan Ham;

MD, Moh Mahfud. 2006. Membangun Politik Hukum, Menegakkan Konstitusi. Jakarta: Pustaka LP3ES Indonesia;

Noor, lemas Masithoh M. "Dinamika Pelaksanaan Fungsi legislasi DPRD Provinsi Dalam Penyelenggaraan Pemerintahan Daerah". Jurnal Litigasi Vol. 10. No. 1. Tahun 2009. Bandung: Universitas Pasundan;

Sulardi. "Penyelengaraan Pemilihan Kepala Daerah Secara Langsung oleh Rakyat Sebuah Upaya Mengurangi Money Politic, Penguatan Kedaulatan Rakyat, Dan Menggeser Arah Pertanggungjawaban Kepala Daerah". Jurnal Legality Vol. 12 No. 12 Tahun 2004. Malang: FH UMM;

Syahrani, Ikhsan. "Pemilihan Kepala Daerah dan Wakil Kepala Daerah Secara Demokratis Berdasarkan Undang-Undang Nomor 32 Tahun 2004". Jurnal Hukum Respublica Vol. 4 No. 2 tahun 2005. Pekanbaru: Universitas Lancang Kuning. 
